\title{
Letters in the earth sciences: written in the past useful in the future
}

\author{
Graziano Ferrari \\ Istituto Nazionale di Geofisica e Vulcanologia, Bologna, Italy
}

\begin{abstract}
This contribution presents a balance of the research performed in some national and international projects concerning the history of seismology with a view to the scientific and historical use of scientific correspondence between earth science scholars. We also present some of the contents of the scientific correspondence studied in the course of those projects. As many scholars and observatories, above all in the 19th century, operated in different sectors of the earth sciences at the same time, we highlight the importance of a coordinated collaboration between scholars and relevant institutions and in valorising the epistolary assets produced by the earth sciences observation networks.
\end{abstract}

Key words scientific letters - earth sciences seismology

\section{Introduction}

Among the historical materials produced by scholars in general, and by the earth sciences in particular, scientific letters play a specific role both in the reconstruction of the scientific pathways towards the design of the seismic instruments at the time and in the analysis of the different phases of development of the science of earthquakes: i.e. seismology.

The first scientific observations of earthquakes, closely connected to the study of meteorology, began around the18th century (Ferrari, 1992a; 1997b); initially with the simple observation of the seismic phenomena, then with the birth of a real science. The first scholars were

Mailing address: Dr. Graziano Ferrari, Istituto Nazionale di Geofisica e Vulcanologia, Sezione di Bologna, Via Donato Creti 12, 40128 Bologna, Italy; e-mail: ferrari@bo.ingv.it interested in observation by designing, planning and often personally building the instruments for earthquake detection and recording (Ferrari, 1992b; 1998). The study of these letters has allowed the reconstruction of the phases of planning, building, honing and functioning of the different seismic instruments. This was the case above all until the end of the 19th century, in other words, as long as letters between scholars was still the most customary system for scientific benchmarking of ideas, theories and experiments $\left({ }^{1}\right)$.

A close mutual relationship among the meteorological, astronomical and seismic observation methods can also be seen in the contents of the letters: one can find meteorological, astronomical, seismic and geomagnetic observations, advice about the design and building of the observation devices $\left({ }^{2}\right)$, theory proofs complete with drawings, tables and diagrams, instrumental recordings and methods for the calculation of earthquake parameters. Scholars often trace connections among the observations of the various phenomena: earthquakes with meteorological displays or with astronomical phenomena, etc. 
In order to better understand the importance of the study of scientific correspondence in seismology it is worth summing up here the objectives and results of some national and international projects on world seismology: the projects TROMOS (1990-2009), the Working Group History of Seismometry of the European Seismological Commission (ESC HoS 1992 present), the Sub-Committee on Historical Instruments and Documents in Seismology (IASPEI S-C 1999-2001) established within the Committee on Education of the International Association of Seismology and Physics of Earth's Interior (IASPEI) and the EuroSeismos Project (ES) for «Saving and Studying the Seismograms of the Strongest Euro-Mediterranean Earthquakes» $\left({ }^{3}\right)$. The informative framework outlined by these projects constitutes the overall historical-scientific context in which to perform rigorous and efficient research into the scientific correspondence in earth sciences addressed to scientific and historical objectives (Ferrari, 2000).

The chief aims of the Tromos project are:

- listing the centres of meteorological and seismic observation operating in Italy from the 18th century to the present day, with details of the present whereabouts of the relevant materials and historical instruments;

- restoring some of the most important historical seismic instruments in Italian meteorological and seismic observatories;

- reproducing the historical seismograms of major Italian earthquakes recorded during this century at European seismological stations and centres;

- publishing the historical and scientific results of the research carried out.

A specific database has been designed for the electronic storage of the indexed information (Tarabusi and Ferrari, 2009). The database of the scientific observation of earthquakes in Italy covers the 18th to 20th centuries. It includes bibliographic, descriptive and illustrative information relating to instruments, observations, scientists and instrument-makers. Over 17,500 historical and scientific sources have been identified and analysed, including scientific publications, recordings in manuscripts, seismic bulletins and letters between scientists. Over 26,500 letters have so far been found and partially filed, microfilmed or scanned. Several hundred letters have been analysed and classified using an original method. Table I summarises the quantitative results of the TROMOS project.

In addition to giving us a historical and scientific picture of the centres, instruments and protagonists of seismology, these historical details represent an indispensable element for a complete historical and cultural framework for planning and carrying out specific research. Since 1997 an internet web site, which has recently been improved, presents the most important information on the instruments, observatories and scholars in Italy from 1730 up to 1950 (Ferrari, 1992b; Tromos website).

\section{Scientific letters in seismology: why and how they are to be recovered}

Scientific letters, of great importance in the history of science and scientific instrumentation, have a particular importance for those sectors of earth sciences in which structured observation networks are distributed across the territory, such as seismology, meteorology, geomagnetism and astronomy.

The very high density of meteorologicalseismic observation points surveyed in the TROMOS project in Italy for the period 17301950 (table I), and of the related seismic instruments and scholars that have operated inside this network, gives some idea of the enormous quantity of letters that were exchanged. This extraordinary research potential provides the chance to reconstruct the scientific and institutional aspects of the different disciplines involved. Founded as observation networks on the private initiative of scholars under the coordination of Francesco Denza (fig. 1a) for meteorology and Michele Stefano De Rossi (fig. 1b) for seismology, these became institutional networks in 1879 and 1887, respectively. The intense correspondence between the people running the nodes of these observation networks, many of which often coincided, makes an important contribution to the history of the observatories and the scientific pathways (fig. 1). Even the most important and substantial let- 
Table I. Quantitative results of both the Italian TROMOS Project and the worldwide IASPEI, ESC and ES projects in the period 1990-2007. Values are approximated and some for the IASPEI, ESC projects not evaluable.

\begin{tabular}{|c|c|c|}
\hline Types of information stored in the database & TROMOS & IASPEI+ESC+ES \\
\hline Bibliographic and documentary sources & 5,500 & 1,000 \\
\hline Meteorological and seismological observatories & 1,100 & 600 \\
\hline Seismic instruments catalogued & 600 & 2,150 \\
\hline Still existing instruments found & 220 & - \\
\hline Restored instruments & 51 & - \\
\hline Historical observatories visited & 50 & 10 \\
\hline Scientists, instrument-makers and addresses of letters & 2,720 & 150 \\
\hline Scientific letters identified and partially reproduced & 26,500 & - \\
\hline History of observatories & 80 & 150 \\
\hline Description of instruments & 150 & 100 \\
\hline Scientific biographies & 120 & 50 \\
\hline Seismograms filed and scanned at SISMOS (1895-1980) & - & 30,000 \\
\hline
\end{tabular}

ters, however, provide a rather half-baked scenario. It is as though we perceived half a dialogue, as though we were listening to a telephone conversation without, however, knowing what the interlocutor is saying at the other end of the line. In the case of the letters, apart from rare case in which we also retrieved minutes of the replies, we witness the opposite: we know what the interlocutor is saying, but do not know the content of the addressee's letters.

The conditions of the historical letter files and the different research interests lead anyone wanting to study the scientific correspondence to follow various approaches: a) study of a letter file; b) cross-reading of scientific correspondence between two or more scholars; c) extensive study of several letter files and their subsequent crossing. It is a distinction made without aiming at classifications, but that only singles out some of the possible research choices.

As seismology and experimental meteorology investigate phenomena that are manifested over great territorial extensions, even its points of observation are spread out and consequently the community of scholars and observers is very broad. The study of individual files (approaches $a$ and $b$ ) had yielded important results in the TROMOS project $\left({ }^{4}\right)$, although approach c) seems to be more suited to returning a more realistic impression of the complexity of the observational networks of the earth sciences.

The quantity of materials to be analysed, catalogued and elaborated, their dispersion in numerous different research institutions (public, private and ecclesiastic) have so far made it extremely hard to reconstruct this history in all its complexity $\left({ }^{5}\right)$.

In order to overcome these problems and to optimise the results of the research, we honed an original method for coding the letters having a scientific interest. Each letter is characterised by the surname, name and location of the sender and the addressee, and the date of the letter. Moreover, 20 codes have been established for the cod- 

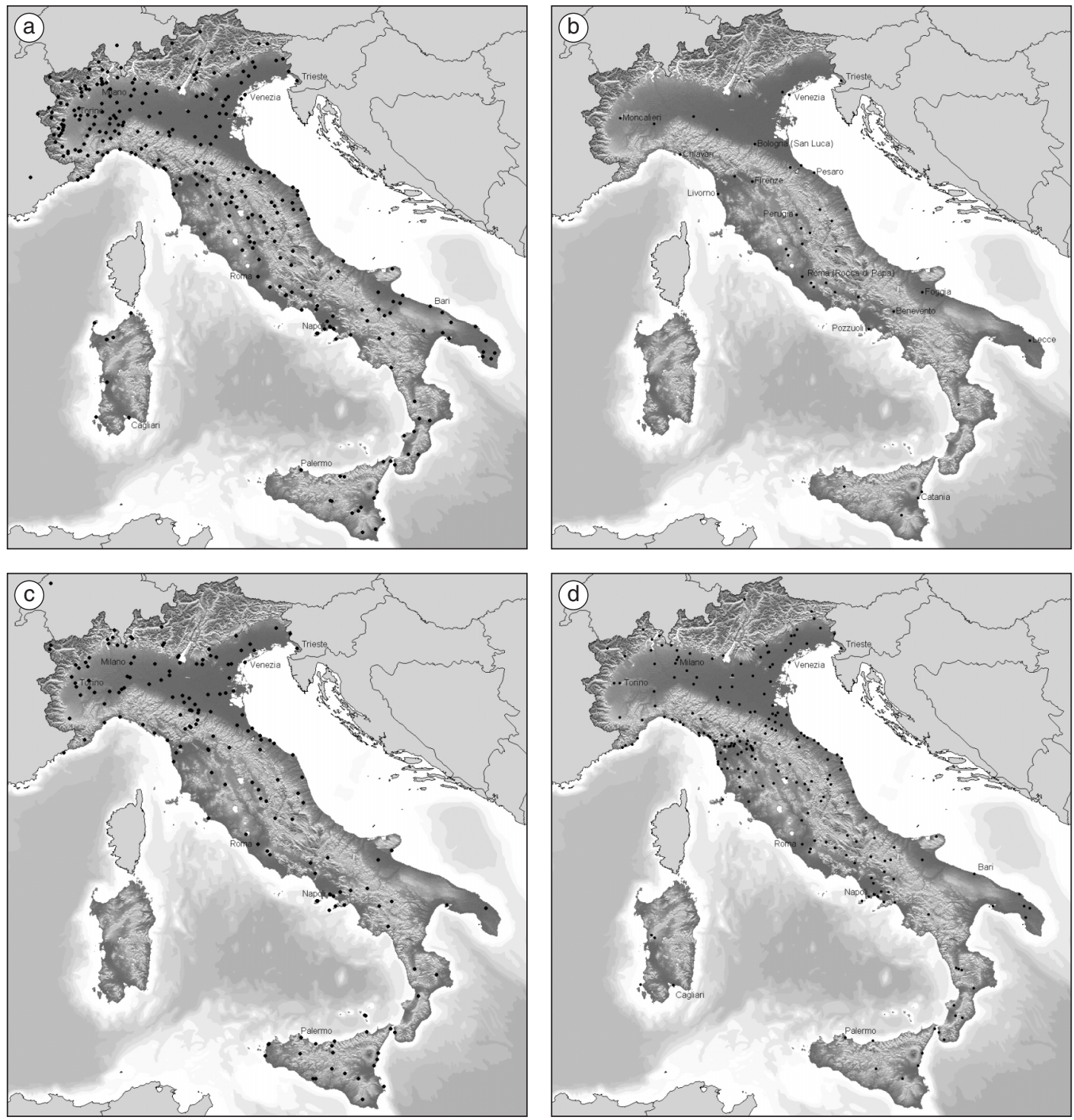

Fig. 1a-d. Maps of the geographic distribution of the correspondents of a) F. Denza; b) M.S. De Rossi; c) P. Tacchini and d) G. Alfani, respectively.

ification and computerisation of the letters; a field in a database corresponds to each code. The field holds the abbreviations of the content of the letter. So each document is identified by the register and by 20 identification fields that are the same for all of the documents. The codification of the contents allows the creation of document subsets with the progressive narrowing down of the quantity of the material to be examined. The registering should produce a brief but effective summary 
(no more than 5 lines) showing the name and surname of the sender, the addressee, abbreviated with initials (Ferrari and Bianchi, 1997).

The current scientific relevance of the content of some historical letters is one of the aspects that have most motivated an investment in this kind of research, by seismologists more than historians of science. The experiences conducted up to now have led us to identify the following types of information: information on the effects of the seismic events; scientific comments to theories, to publications, etc.; graphs; reproductions of seismograms; news of loans of recordings; information and drawings of instruments, their location and orientation within the observatories.

The first three information types do not require particular comments, while the others are very important for seismological research and it is worth examining several aspects in detail.

Among the hundreds of the world's seismological observatories that have recorded earthquakes ever since the early 1890 s, unfortunately not all of them kept their recordings archives intact. In many cases these were partly or totally destroyed by myriad causes: human (state of abandonment, deliberate destruction or wars) and natural (fires, earthquakes, floods, etc.). At times the recordings of the most important earthquakes have been lost, with serious harm done to research $\left(^{6}\right)$. The reproductions of seismograms and/or information relating to them that can be found in several letters, opportunely re-interpreted according to the current methods of analysis, can still provide important elements that can return part of the information lost. Figure 2 shows an example of this kind of letter. Emilio Oddone writes to an unidentified foreign colleague, but from some elements probably Albin Belar, providing him with information as to the seismic recordings at Pavia of the earthquake at Ljubljana on 14th April 1895 and offering him a photographic copy of such recordings, of which he nevertheless supplies an ink sketch enclosed in the letter $\left(^{7}\right)$.

The letters requesting the loaning of seismograms are very valuable because in the previously cited cases in which loaned seismograms were not returned it is possible to trace back those who benefited from the loan in order to attempt the retrieval even many years afterwards. In other cas-

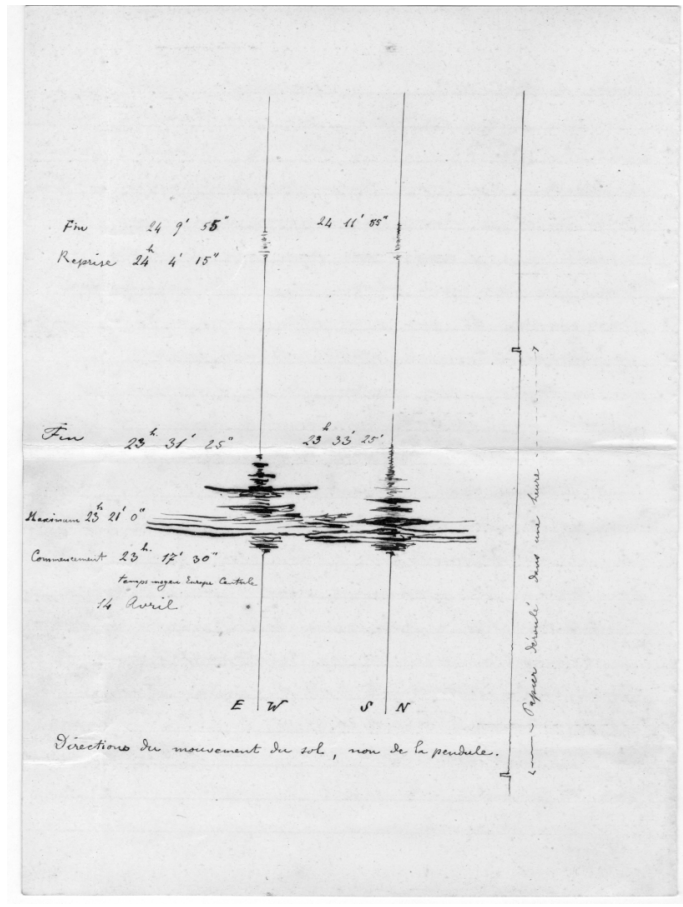

Fig. 2. Letter from Emilio Oddone probably addressed to Albin Belar, director of the observatory of Ljubljana concerning the earthquake on 14th April 1895. The image reproduces the seismogram of the earthquake as recorded at Pavia (INGV Archive, Rome).

es, the information from the letters that refer to the borrowing of original data can orient us towards deepening our research and tracing in disorganized archives the original documents that were thought to be lost. For instance, in the rather haphazard Giulio Grablovitz archive, some seismograms of the earthquake of the Straits of Messina which occurred on 28th December 1908 , and recorded in the observatories of the Island of Ischia, had gone amiss. A circular letter from Omori to Grablovitz, with the request for seismograms and magnetograms, reports a handwritten note in which Grablovitz states he had sent the photographs of two seismograms and a calqued transparency, of the graph mareographic tracing of the earthquake (fig. 3 ).

Letters with information on the methods for 


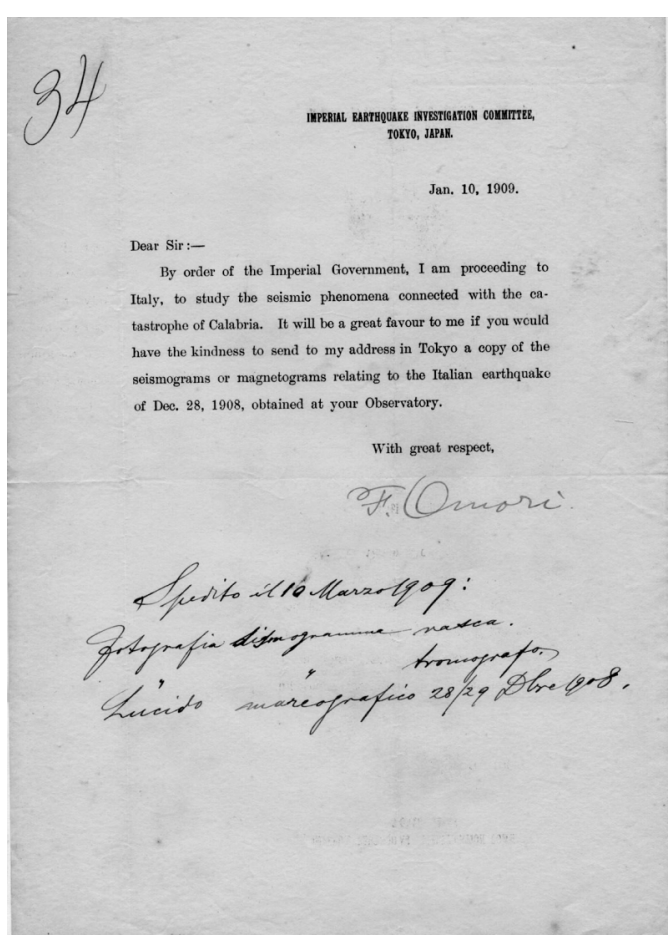

Fig. 3. Circular letter of Omori to Grablovitz with the request for copies of seismograms and magnetograms connected with the earthquake of the Straits of Messina on 28th December 1908. A handwritten note of Grablovitz specifies that on 10th March 1909 copies of the seismograms were sent and a glossy calqued copy of the mareogram (Grablovitz Archive).

installing the instruments, their characteristics and orientation are not rare and often supply data that would otherwise be lost, essential for the interpretation of historical seismic recordings $\left({ }^{8}\right)$.

At times the letters provide us with useful information for correcting the published data which, as such, are a point of reference in daily scientific practice. Two cases are presented here: correspondence between G. Grablovitz and Giovanni Agamennone on a mistaken use of Grablovitz's mareographic data by Fusakichi Omori, and letter from Pietro Caloi to Beno Gutenberg, in which the Italian seismologist points out some errors in the formulae of a recent article of his.
In 1914 Agamennone wrote to Grablovitz, criticising the conclusions that Omori draws on the possible correlation between the variations in the level of the Mediterranean and the CalabriaMessina earthquake on 28th December 1908 (Omori, 1911). Agamennone invites Grablovitz, as an expert of tidal-wave measurements as well as seismological matters, to review the calculations and the considerations made by Omori. If they were wrong, according to Agamennone, it would not be the first time that Omori had reached over-hasty conclusions without the proper experimental evidence $\left({ }^{9}\right)$ (fig. 4 ).

Grablovitz confirmed that he too had read the article by Omori and that he was puzzled about the strong variations in the sea level reported by Omori (Archivio Grablovitz, 20th January 1914). While intending to analyse the fascinating hypothesis put forward by the Japanese seismologist at greater depth, Grablovitz immediately noticed some errors in Omori's use of the Ischia tidal-wave data published by Grablovitz (1911) and concluded that, in his opinion, such strong variations had a mainly meteorological origin. He also said that he had informed Omori of his observations, receiving a reply that allowed for a correction in a subsequent issue of the Bulletin of the Imperial Earthquake Research Committee.

The complexity or even the impossibility of directly checking the validity of the data that underlie scientific studies, such as in the case of the study of Omori (the subject of the correspondence between Grablovitz and Agamennone), oblige the subsequent authors to place their trust blindly in the quality of the data and the subsequent elaborations. If the conclusions of the works are then used for other elaborations a propagation of errors may arise that is not immediately detectable. In this case, it does not appear that Omori did indeed make the promised correction, so his conclusions, and therefore the use of his study, is a potential source of errors for studies that have used or would use his conclusions.

In a letter dated 19th December $1946\left({ }^{10}\right)$, Pietro Caloi pointed out to some errors to Beno Gutenberg in the formulae of the article on the energy ratio of reflected and refracted seismic waves (Gutenberg, 1944). In his letter dated 


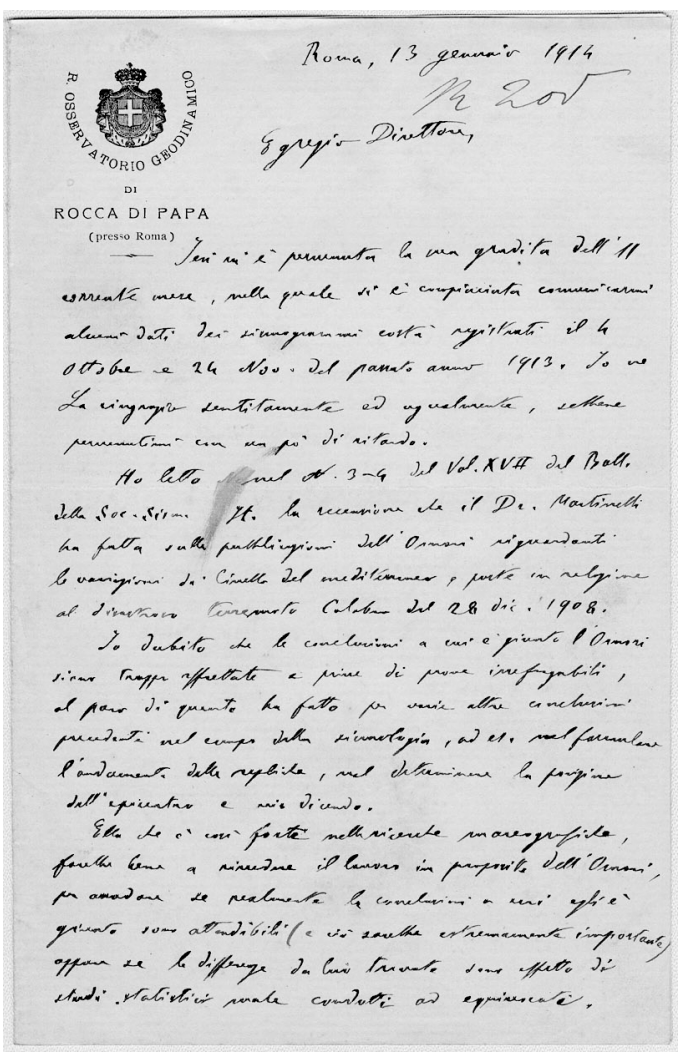

Fig. 4. First sheet of the letter from G. Agamennone to G. Grablovitz of 13th January 1914 with the invitation to examine more thoroughly the use that F. Omori had made of the mareographic data of Ischia for his study at on the sea-level variation connected with the earthquake of the Straits of Messina on 28th December 1908 (Grablovitz Archive).

15th January 1947 (fig. 5), Gutenberg replied to Caloi confirming the appropriateness of all his corrections and acknowledged that Caloi was probably the only one who had read his article very carefully. In those days Caloi was already enjoying a certain prestige at international level, so much so that only a few years later he sowed the seeds, with Inge Lehmann, for the creation of the European Seismological Commission $\left({ }^{11}\right)$. In 1958, on the occasion of the publication of a celebrative volume of Beno Gutenberg, Caloi was one of the few European seismologists invited to contribute a text (Caloi, 1958). In other cases, the letters help us to understand important moments in the history of a discipline.

Important epistolary documentation found in the Italian and English archives contributes crucially to enriching, for example, Robert Mallet's account of his scientific mission in the areas of the earthquake that occurred on 16th December $1857\left({ }^{12}\right)$. The faithfulness with which the Irish scholar echoed large extracts of his letters in his own report (Mallet, 1862) gives us proof of two important aspects: the great accuracy of his working method and documentation, and the authenticity of the emotions he experienced in his intense scientific and human experience in the desolate earthquake areas.

The rich documentation comes from the epistolary archives of Alexis Perrey, Charles Lyell, the Royal Society of London and others, respectively $\left({ }^{13}\right)$ and tell of Mallet's scientific mission, the preparations behind the field action, and the long and wearying negotiations to get his bulky report published unabridged (Ferrari and McConnell, 2005). Of great importance is the documentation of the State Archive of Naples, also made up of letters, which describe the diplomatic and the police background to Mallet's mission, at a time of diplomatic crisis between the United Kingdom and the Kingdom of Naples. During his scientific mission, Mallet mainly wrote to Lyell and Perrey, testifying to his emotions as well as making scientific considerations $\left({ }^{14}\right)$. The latter were based on various aspects, amongst which, in particular, the earthquake, the natural environment, the geology.

It is from the earthquake «front» that Mallet submitted his request for a further 50 pounds for a photographic report to be commissioned to Claude Grillet, a French photographer in Naples (Ferrari, 2007a). Mallet wrote and sent letters but could not receive any, as he was always on the move, and received the replies to his letters only upon his return to Naples.

The dramatic nature of the situations experienced by Mallet and the emotions he experienced in Saponara (today Grumento Nova) are conveyed by the Irish seismologist with great suggestiveness and were immediately followed by considerations on the building inadequacy of the houses. These are letters that Mallet wrote in the short breaks when he, his men and their 


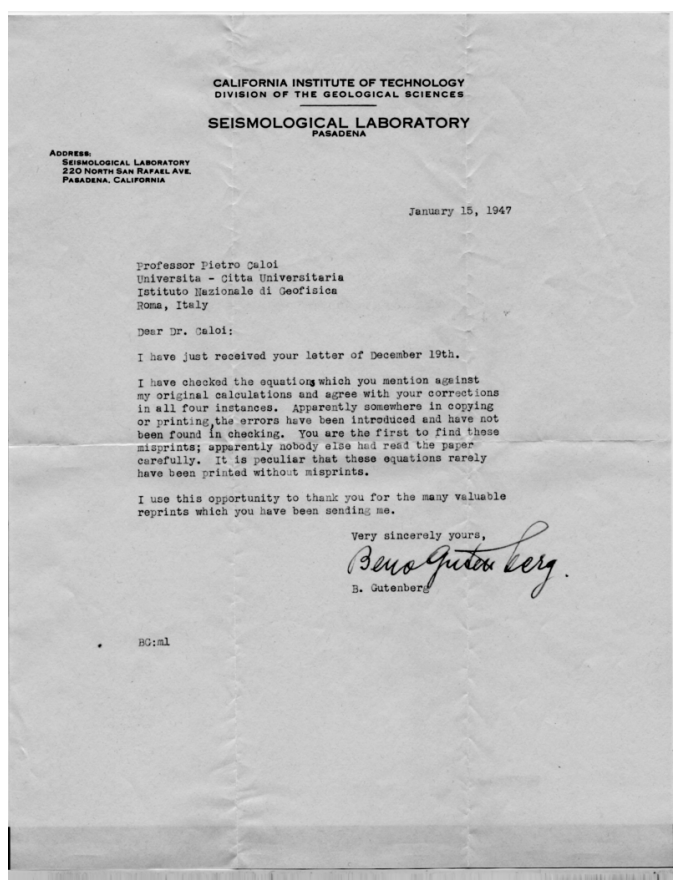

Fig. 5. Letter from Beno Gutenberg to Pietro Caloi in which he confirms to the Italian seismologist that the corrections to his work (Gutenberg, 1944) which he had pointed out, were right and he thanks him for the attention with which he had read his work.

animals, could rest. On 24th February, after a reconnaissance of the damage to the monastery of Monticchio on Mount Vulture, Mallet started his return journey towards Naples. Between Atella and Bella, Mallet had to cross the Passo delle Crocelle passing north-westwards of Monte Santa Croce. The task was an emotional and very difficult one owing to the heavy snowfall that had covered the path; it was 60 to 250 $\mathrm{cm}$ deep and made the path impracticable. In a letter to Lyell sent from Naples, dated 1st March, this is how he summed up the situation on the spot: «The landscape is wild and I have spent several nights in scenes that made me strongly desire to possess the powers of a Salvator de Rosa to be able to transfer them onto canvass» $\left({ }^{15}\right)$. It is curious to observe how in the letter to Lyell, in evoking the powers of Salva- tor Rosa, Mallet was still all taken up by the territories he had crossed and by the very personal landscape depictions of the Neapolitan baroque painter, while in the reconstruction of that adventurous crossing in the snow, recounted in his Report, the Irish scientist pieced together those emotions citing a painter much better known at international level - Caravaggio (Mallet, 1862, vol. 2, p. 121).

Lastly, the letters at times offer us some behind-the-scenes situations, on the margins between public and private, concerning events that have accompanied the major turning points in the history of a discipline. A case in point is De Rossi's removal from the role of coordinator of the national geodynamic service at the end of the 1890s. As mentioned above, starting from the mid-1870s, De Rossi had been the protagonist, in part with Timoteo Bertelli, of a lively pioneering period in which he promoted and set up the first instrument observation network of earthquakes in Italy and the first geodynamic Journal in the world: the Bullettino del Vulcanismo Italiano (Bulletin of Italian Volcanism). In the wake of the growing popularity earned by De Rossi among the scholars of seismic phenomena in Italy, and thanks to the interest of Felice Giordano, Chief Inspector of the Corpo delle Miniere, in 1883, De Rossi was summoned to set up an Observatory and Central Geodynamic Archive at the Geological Service. After a long and laboured political and administrative path, the geodynamic service was established in 1887 . For economic reasons, the service could not be set up autonomously but was put beside the Central Office of Meteorology (COM), directed by Pietro Tacchini. De Rossi appeared to be the natural director of this new service and this would have been the fitting crowning of nearly twenty years' scientific work and promotion of seismological research in Italy, an activity which, amongst other things, was highly appreciated abroad. However, De Rossi was too independent with respect to the thinking of the bureaucratic and administrative powers that be, being keener on scientific research than on bureaucracy, so much as to often seem the victim and scapegoat for the inefficiencies of the State administration. In this regard, the row that erupted over the construction of the Observatory of Rocca di Papa is 


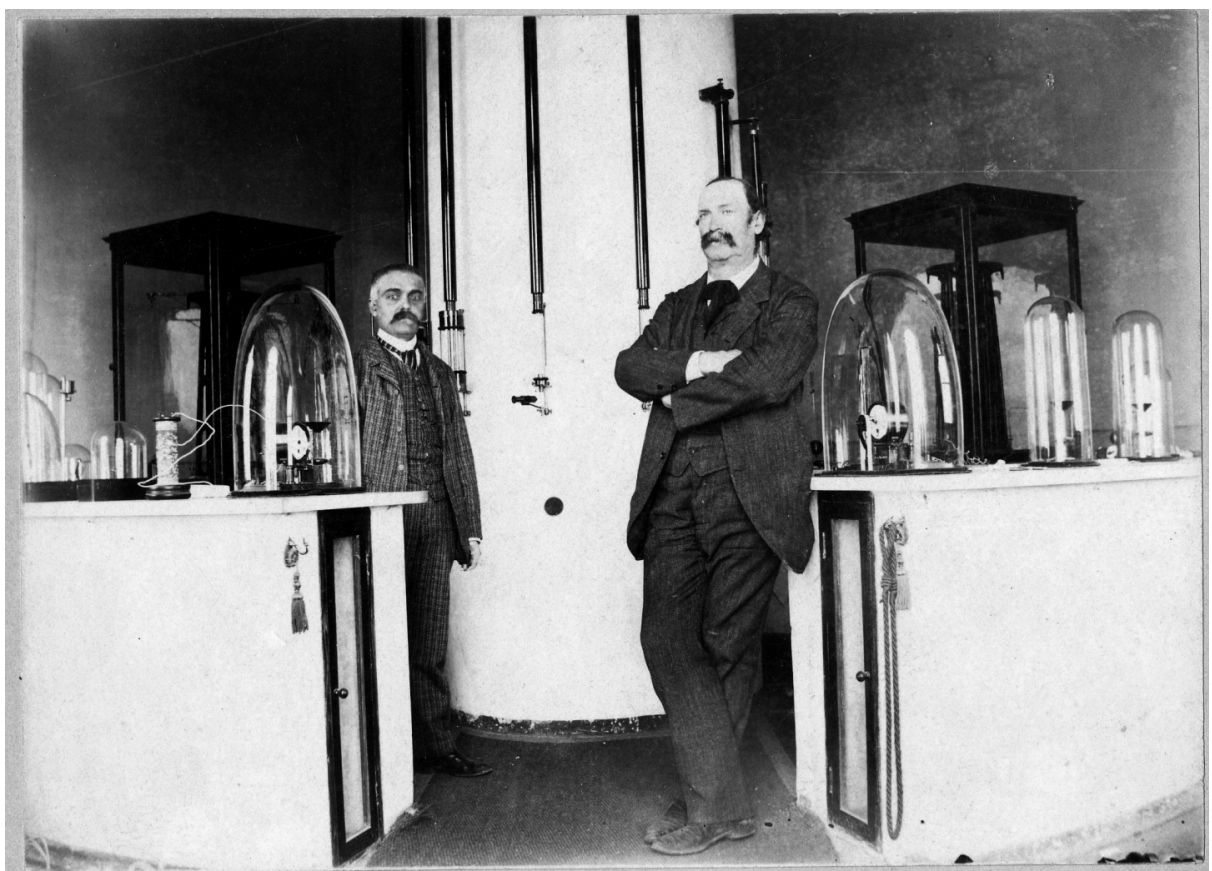

Fig. 6. Michele Stefano De Rossi and his assistant at the Rocca di Papa Observatory in a picture dating back to the 1890s (De Rossi Private Archive, Geneva).

emblematic, one of the four which the Royal Geodynamic Commission, chaired by Pietro Blaserna, had resolved to build in 1884 (Ferrari, 2009). It was Blaserna himself who, in reply to the accusations from the Ministry of Agriculture, Industry and Commerce, which the meteorological and geodynamic services were answerable to, regarding the higher costs needed for the construction of the Rocca di Papa Observatory, mostly put the blame on De Rossi, accusing him of not having adapted to the new orientations in science and of having designed a «medieval castle» rather than a geodynamic observatory $\left({ }^{16}\right)$.

After attacks such as these, Tacchini met De Rossi on 27th July 1891 and delivered the decisive blow that removed this pioneer of Italian seismology from the role of director of the geodynamic service. After having «used» him, the moment had by then come for the institutions of the day to demote De Rossi to the mere role of director of the new observatory of Rocca di Pa- pa (fig. 6). In the letter in which Tacchini reports the outcome of this meeting to Miraglia, the phrase with which he concludes the letter effectively sums up the tone of the about-turn that was about to be made: «We must hold on, and once the blow has been inflicted, we need to hold on to it at any cost» $\left({ }^{17}\right)$.

Among the original outcomes of this kind of correspondence is what could seem to be «scrap material», i.e. letters concerning the bureaucracy and the proper functioning of observatory that was our observers' the scientific laboratory. On the contrary, these letters serve to reconstruct the history of the observatory or the research headquarters in general. Sites whose history was mixed and confused with that of the scholars who spent most of their lives there, which rarely has equivalents in other contexts. For seismologists and meteorologists the subject of the observation is outside the laboratory, it is around them. 
The more than 14,000 letters catalogued and analysed within the scope of the TROMOS project have allowed us to successfully test the comparison between letter files from different historical sites of meteorological, seismic and astronomical observation.

The fruitful research performed hitherto on the scientific correspondences of seismology has convinced us of the need and appropriateness of broadening the project horizon to all the earth sciences.

\section{From seismology to earth sciences}

Within the framework of a broad international collaboration in the projects IASPEI S-C and ESC HoS, implemented in the wake of the TROMOS project, the idea of following a specific research path and collaboration in the scientific correspondence in the earth sciences was born. It is true that the experience performed hitherto mainly concerned the seismological field and at most meteorology, but is should nevertheless be observed that the disciplinary distinction is rather recent and that in any case in Italy the meteorological and seismic observation has often been conducted in long-established astronomical observatories. Thus the materials, observations and history of distinct disciplines mingle together. The astronomical observatories of Brera at Milan, Turin, Piacenza, the Collegio Romano in Rome, Capodimonte in Neaples and Palermo, to mention just a few, are some examples of how a historical Italian astronomical institution constituted the natural home that hosted, first the meteorological observation, and then the seismological one. The coinciding on the same site of astronomical, meteorological and seismological observation has both an organisational motivation, being more economical and functional, but also a scientific one. It should not be forgotten, for example, that astronomical observation is strongly affected by the meteorological status of the observation site and of a vast area around it, and that it was in the astronomical field that earthquakes imperceptible to man were perhaps observed for the first time $\left({ }^{18}\right)$. Moreover, for various decades at the turn of the 19th-20th cen- turies the astronomical observatory was the only one capable of guaranteeing the most accurate hourly synchronisation of the seismic instruments for those times $\left({ }^{19}\right)$. Only since the early 1920s, and only in the less well-equipped observatories (Ximeniano of Florence, Rocca di Papa) was the hourly synchronisation performed with the reception of radio time signals.

Numerous and largely identified files of historical correspondence of interest for meteorology and astronomy lie unused, uncatalogued, and even at risk of dispersion. The problems of cataloguing them and above all managing them with as view to consultation for study purposes have often been a disincentive preventing the preservation work from ever getting started.

Within the scope of the TROMOS project the letters of the observatories of Chiavari and Piacenza, have been scanned and there are plans to digitally scan the files of scientific correspondence at the observatories of Casamicciola, of Ximeniano Florence, Foggia and in general of the most important historical Italian observatories. The catalogues and scans are conducted in collaboration with the conservatories of documentation, public or private, and to their benefit.

The letters of the files Bertelli and Tacchini have already been scanned electronically at the Centro Studi Barnabiti of Rome (transferred there from its original site of production and preservation, the College «Alla Querce» of Florence) and the Ufficio Centrale di Ecologia Agraria in Rome respectively. It is no coincidence that the first systematic digital scan was performed on Tacchini's file: he was the astronomer, «meteorologist» and «seismologist», at least from the institutional point of view. The digital archive hitherto produced gathers together over 5,000 letters, for a total of over 10,000 pictures, received by Tacchini and Bertelli from over 800 correspondents, all surveyed in the TROMOS database and documented by all the biographical information available.

The modern computer technologies allow us to store and distribute on the web the most diverse information forms and thus make it possible to realise what only a few years ago was unthinkable: a single archive of letters relating to the scholars of Earth Sciences. 
The project, broadened to the wider community of scholars, aims to promote and foster the identification, cataloguing, and lectronic scanning of the letters, thus making the files available to students for the study of the history of earth sciences and astronomy.

Parallel to the project we also aim to promote the recovery in electronic format of everything hitherto published: catalogues of letters, registers, integral letter transcriptions; this phase should also be flanked by a digital scanning of the letters themselves.

The international community of scholars would benefit greatly from this if the Italian version of the catalogue and the registers of the letters were supported by translations into English.

Cataloguing, scans and online availability will have to be performed respecting legal rights and by specific agreements stipulated with the public or private bodies conserving the files subject to the study. It is important and not superfluous to mention this fact, as the success of wide-ranging operations such as this one also depends on the quality of the collaboration with the institutions actually preserving the documents.

The SISMOS research team of INGV deals with the search for, recovery, reproduction and valorisation of the enormous historical assets of Italian as well as European seismology. It is currently involved in the large-scale reorganisation of its own database, capable of receiving all the historical-scientific information from the projects of Tromos, EuroSeismos and Letters in Earth Sciences. Part of the database will make up the national historical digital library on the topics of the scientific observation of earthquakes in Italy and will at last allow us concomitant access to all the published and unpublished documentation that «tells» the extraordinary experience of Italian seismology in the context of world seismology.

\section{Notes}

( $\left.{ }^{1}\right)$ Very significant in this sense is the intense correspondence between M.S De Rossi, Timoteo Bertelli, Giovanni Cavalleri, Pietro Monte, Antoine d'Abbadie and others regarding the nature of the pendular movements (tromometric from tromometer, the instrument invented by Bertelli and perfected with observations by Bertelli and De Rossi). The correspondence is filled with drawings, suggestions, comparisons. For a more complete discussion of this matter, see: FERRARI, 1992a.

$\left.{ }^{(}\right)$Examples of letters with project drawings of instruments or their parts and with diagrams have been published in FERRARI, 1991, pp. 24, 27 and 58.

$\left({ }^{3}\right)$ Over the past 20 years the author has promoted and coordinated the implementation of all of these projects and working groups and is currently in charge of the SISMOS research team of the INGV in Rome, which, besides its own activity of searching, reproducing and scientifically and historically valorising the Italian and European seismological tradition, will embrace all the goals and products of these projects. The aims and the main results of these international working groups have been published in FERRARI, 1997b; 2000, TARABUSI and FERRARI, 2009 and EuroSeismos web site 2002-2009.

$\left({ }^{4}\right)$ The task of scientists like Timoteo Bertelli and Michele Stefano De Rossi, who constantly wrote letters each other, led to the developing of tromometers, instruments able to detect the slightest oscillations in the soil. The microseism observing technique improved until the distribution of the standard tromometer, a pendulum whose overall length is approximately $150 \mathrm{~cm}$, able to take the slight and slow movements of the soil. It is estimated that in more than 50 public and private observatories more than 300,000 tromometric measures have been taken 5,000 of which analysed scientifically in FERRARI et al., 2000. For the birth and the development of the tromometer, see FERRARI, 1992b, pp. 64-70 and FERRARI, 1992a.

$\left({ }^{5}\right)$ Materials of all sorts have been traced in the course of the TROMOS project in all kinds of environment conditions. Some letters have been preserved in excellent condition, others have been spoiled by the wear and tear of time or by mutilation due to the removal of the stamps. Letters and manuscripts have been microfilmed on $16 \mathrm{~mm}$ or scanned. 
$\left(^{6}\right)$ The seismologists using the seismograms of historical earthquakes for studies on the seismic potential and risk of given areas well know this, because often seismograms fundamental to research are missing, surely recorded but lost, quite often because lent out in the past and never returned.

( ) Letter of Emilio Oddone, director of the Regio Osservatorio Geodinamico of Pavia, to Prof. A. Belar (?), Pavia 4th May 1895, kept in the Archive of the Istituto Nazionale di Geofisica e Vulcanologia of Rome. The letter starting like this: «Très illustre Professeur. J'ai suï que vous travaillez au sujet du tremblement de terre de Laibach [...]» seems to be addressed to Albin Belar the director of the seimological observatory of Ljubljana. In the letter Oddone reports the data of the recordings at Pavia of the earthquake at Ljubljana on 14th April 1895. $\left({ }^{8}\right)$ See for some of these letters CERINI and FERRARI, 2009 and BATLló, 2009.

$\left({ }^{9}\right)$ From the Grablovitz Archive: Letter from G. Agamennone to G. Grablovitz, 13th January 1914 and Letter from G. Agamennone to G. Grablovitz, Rome, 18th February 1914:

«[...] È con vero piacere che ho appreso dalla sua gentile lettera che ha già pensato a rivedere i calcoli di Omori relativi alle supposte eccezionali variazioni del livello marino intorno all'Italia in correlazione con il terremoto del 28 dicembre 1908.

La statistica è una cosa meravigliosa, ma uno deve essere in grado di usarla molto cautamente e con moderazione altrimenti, specialmente con idee preconcette, possono dare risultati come vogliamo che vengano. E, a mio parere, è molto utile per la scienza di rettificare ciò di più assurdo che comunemente è pubblicato per épater les imbecilles. Anche io sono un ammiratore del Prof. F. Omori, ma sono convinto che, per il supremo interesse della scienza, uno non deve avere troppi scrupoli a criticare, con la dovuta cortesia, qualsiasi lavoro che sollevi seri dubbi. In ogni caso, avete fatto bene a scrivere di Omori in primo luogo, che probabilmente si affretterà a fare le correzioni $[\ldots] »$

Translation: «[...] It is with pleasure that I have learned from your kind letter that you have already thought of reviewing Omori's calculations concerning the supposed exceptional variations in the sea level around Italy in correlation with the earthquake on 28th December 1908. Statistics is a wonderful thing, but one has to be able to make use of it very cautiously and with moderation otherwise, especially with preconceived ideas, they can be made to say whatever you want them to. And, in my opinion, it is very useful for science to rectify the much nonsense that is commonly published pour épater les imbecilles. I too am a wholehearted admirer of Prof. Omori, but I am convinced that before the supreme interests of science, one must not have too much scruple in criticising, with all due politeness, any work that raises serious doubts. In any case, you have done well to write to Omori first, who will probably hurry to make the corrections [...]».

$\left({ }^{10}\right)$ Archivio Pietro Caloi, Copy of the Letter of Pietro Caloi to Beno Gutenberg:

«Roma, 19 dicembre 1946

Prof. Beno Gutenberg

Seismological Laboratory PASADENA-

Illustre professore, La ringrazio molto della cortese Sua del 24 ottobre scorso, e del preannuncio dell'invio delle Sue pubblicazioni, che spero ricevere quanto prima.

Nel frattempo, sono riuscito ad avere qualcuno dei Suoi ultimi lavori, che sto leggendo con tutto l'interesse richiesto dalla scelta degli argomenti e dall'autorità dell'Autore. Fra l'altro, sto consultando le prime pagine della Sua notevole ricerca «Energy Ratio of reflected and refracted seismic waves» (Bull. S.S. of A., Vol. 34, April 1944). A questo riguardo, vorrei che Ella fosse così cortese da darmi un chiarimento. Ecco di che si tratta. A pagina 87, la seconda delle formule (7b) é scritta $\mathrm{M}=\sqrt{\cos \eta / \cos \alpha}$; senonchè, partendo dalle equazioni di Knott, a me risulterebbe $\mathrm{M}=\sqrt{\operatorname{cotg} \eta} / \operatorname{cotg} \alpha$. In questo caso però, tenuto conto della seconda delle (7a), sarebbe $\mathrm{M}=\frac{1}{\mathrm{j}}$, e l'introduzione del simbolo $\mathrm{M}$ non
avrebbe ragion d'essere.

A pagina 89 poi i secondi membri delle (13e) e (13f) dovrebbero essere preceduti dal segno - , mentre la (13g) dovrebbe essere scritta $\frac{\mathrm{f}}{\mathrm{e}}=\frac{\mathrm{j}+1 / \mathrm{j}}{\mathrm{j}-1 / \mathrm{j}} \frac{\mathrm{IL}+1}{\mathrm{I}-\mathrm{L}}$.

Le sarò grato se vorrà darmi una risposta sulla giustezza o meno di queste osservazioni.

Gradisca, Illustre professore, molti distinti saluti. (Prof. Pietro Caloi).»

Translation: «Most Honourable Professor, I wish to thank you kindly for your letter dated 24th October, and the forewarning that your publications are being sent, and which I hope to receive soon.

In the meantime, I have managed to get some of your latest works, which I am reading with all the interest demanded by the choice of the topics and by the author's own authority. Amongst other things, I am viewing the first pages of your remarkable research entitled «Energy Ratio of Reflected and Refracted Seismic Waves» (Bull. 
S.S. of A., Vol. 34, April 1944). In this regard, I would like you to be so kind as to give me some clarification. This is the point at hand. On page 87 , the second of formulae (7b) is written $\mathrm{M}=\sqrt{\cos \eta / \cos \alpha}$; thus, starting from the equations of Knott, I get $\mathrm{M}=\sqrt{\cot g \eta / \cot g \alpha}$.

In this case, however, bearing in mind the second of the $(7 \mathrm{a})$, would be $\mathrm{M}=\frac{1}{\mathrm{j}}$, and the introduction of the symbol $\mathrm{M}$ would not have any reason to exist.

Then on page 89 the second members of the (13e) and (13f) should be preceded by the sign -, while the (13g) should be written $\frac{f}{e}=\frac{j+1 / j}{j-1 / j} \frac{I L+1}{I-L}$.

I should be grateful to you if you would give me a reply as to the correctness, or lack of correctness, of my observations. My sincerest best regards. (Prof. Pietro Caloi)».

$\left({ }^{11}\right)$ From an idea of Inge Lehmann and Pietro Caloi, on 1950 in Verona the European Seismological Federation was born, with I. Lehmann as president. Only in the 1951 it changed in the European Seismological Commission (LEHMANN, 1971, HJORTENBERG, 2009).

${ }^{12}$ ) On 16th December 1857 an earthquake devastated a vast area of the regions of Basilicata and Campania (Val d'Agri and Vallo di Diano). Furthermore, 180 localities together with more than 6,000 dwellings were destroyed and the number of dead ranged between 11,000 and 19,000. In February 1858, he was awarded a bursary by the Royal Society of London, with the aim of verifying his theory published in 1848. In 1862 he published the results of this study in the earthquake field (FERRARI and MCCONNELL, 2005).

$\left({ }^{13}\right)$ The main archives and libraries where are preserved letters used by the author to reconstruct many aspects of the Mallet journey in the field of the 1857 earthquake are: Armagh Observatory Library; Biblioteca della Società Napoletana di Storia Patria, Naples; Cambridge University Library; Edinburgh University Library; Archives of the Geological Society of London; Archives of the Royal Society of London.

$\left({ }^{14}\right)$ Edinburgh University Library, Lyell 1/cc.4034-4049.

$\left({ }^{15}\right)$ Edinburgh University Library, Lyell 1/cc.4038-4043.

$\left({ }^{16}\right)$ Letter of Pietro Blaserna to the Ministry of Agriculture, Industry and Commerce, Rome 1st November 1889. «Consiglio Direttivo di Meteorologia e di Geodinamica, Roma 1 novembre 1889

a S.E. il Ministro di Agricoltura, Industria e Commercio.

Ritornato da un viaggio all'estero, ho trovato qui la lettera del 31 agosto, la quale mi prova come V.E. sia stata men che esattamente informata. Il progetto per l'osservatorio di Rocca di Papa fu dal Ministro approvato senza che persone competenti fossero state interpellate. E si che l'amministrazione sapeva, come dopo due lunghi anni di discussione in seno alla Commissione Reale il Direttore di quell'osservatorio (De Rossi) non aveva né saputo né voluto convincersi del nuovo e prettamente scientifico indirizzo, che la Commissione intendeva dare al servizio geodinamico. [...]

L'osservatorio di Rocca di Papa non doveva costare più di lire 20.000; se finirà di costare più di 50.000 e se da ciò ne è venuto il discredito del servizio, la colpa è tutta e intera dell'amministrazione. Né vale il dire che per Casamicciola si è consentito di più. I movimenti sismici dell'Isola d'Ischia sono ben altrimenti importanti che non quelli del cratere laziale; ed il Direttore di Casamicciola è il solo, dico il solo dei nostri direttori, il quale abbia indirizzo veramente scientifico. Nessuna di queste ragioni vale per Rocca di Papa; ed è perciò che non posso modificare il severo giudizio che ho portato sul conto dell'amministrazione. [...] Può essere una disgrazia, per individui come per nazioni, l'essere poveri; ma io conosco un'altra disgrazia ben maggiore, ed è quella di essere più ricchi di quanto la propria istruzione lo comporti. Quei tagli, che hanno fermata la geodinamica e compromesso la meteorologia, non giovano a nessuno; il bilancio non se ne accorge ed è ciò che costituisce la parte dolorosa della questione. [...] Il Direttore dell'Istituto Pietro Blaserna».

Translation: «Upon returning from a trip abroad, I found here this letter dated 31st August, which shows me how V.E. was less than exactly informed. The project for the observatory of Rocca di Papa was approved by the Ministry without competent people having been summoned. And the administration knew, after two long years of talks within the Royal Commission, the Director of that observatory (De Rossi) neither knew nor wanted to believe in the new and strictly scientific orientation, that the Commission wanted to give to the geodynamic service [...].

The observatory of Rocca di Papa could not cost more than 20,000 lire; if it ends up costing more than 50,000 and if from that the service has suffered discredit, the fault is entirely down to the administration. It should be said that for Casamicciola more was allowed. The seismic movements of the island of Ischia are far more important than those of the Lazio crater; and the Director of Casamicciola is the only one, the only one of our Directors I say, who has a truly scientific orientation. None of these reasons applied to Rocca di Papa; and that is why I cannot alter the strict judgement that I have made on account of the administration. [...] It may be a mis- 
fortune, for individuals and for nations, to be poor; but I know of another much greater misfortune, and that is of being richer than one's own education requires. Those cuts, which have stopped geodynamics and compromised meteorology, benefit no one; the balance does not change and that is what makes up the painful part of the matter. [...] The Director of the Institute, Pietro Blaserna».

$\left({ }^{17}\right)$ Confidential message of Pietro Tacchini to the General Director of Agriculture Nicola Miraglia on the controversy with De Rossi M.S. in regard to the Observatory and the General Geodynamic Central Archive of Rome, Rome 27 July 1891, cc. 3, Archivio Centrale dello Stato, Direzione Generale dell'Agricoltura, V versamento, busta 540, fasc. 320, Letter of Pietro Tacchini to Nicola Miraglia:

«Ill.mo Direttore, [...] Questa mattina venne da me il De Rossi come una furia, e so che ieri a Rocca si è sfogato contro l'Ufficio. Infine però visto che io non mi arrendevo, capitolò riservandosi però di far valere i diritti presso il Ministero [...] In quanto all'Archivio egli disse che è proprietà letteraria sua!! E che perciò si dovrebbe portare ogni cosa all'U[fficio] C[entrale] e venire lui a fare l'archivista!! Risposi impossibile, e piuttosto, gli suggerii di chiedere al Ministero che i libri e strumenti di S. Susanna già da lui inventariati, siano invece destinati all'Osservatorio di Rocca di Papa, che non ha libreria; io non mi presi impegno per ciò, ma dissi solo che non credevo difficile ottenere su ciò il consenso del Ministero.

Dopo questa spiacevole discussione lunghissima, egli venne a parlare delle cose dell'osservatorio di Rocca e non fu difficile l'intenderci e su ciò farò rapporto al Ministero; mentre delle altre cose mi limito a riferire a lei colla seguente. Bisogna tener duro e fatto il colpo mantenerlo a qualunque costo».

Translation: «Most Honourable Director, [...] This morning De Rossi came to me like a fury, and I know that yesterday at Rocca he let go of himself against the Office. Finally, however, seeing that I did not give in, he capitulated saying that he would nonetheless go to the Ministry to have his rights upheld [...]. As regards the archive, he said that it his own literary property!! And that therefore everything should be taken to the C[entral] O[ffice] and he should come to be the archivist!! I answered that it was impossible, and rather suggested to him to ask the Ministry for the books and instruments of Santa Susanna that he had previously inventoried, to be destined instead to the Observatory of Rocca di Papa, which does not have a library; I did not make any commitment on this, but only said that I did not think it would be hard to obtain this with the permission of the Ministry.

After this unpleasant and very lengthy discussion, he went on to speak of matters concerning the observatory of Rocca and an understanding was not hard to reach and on this. I will report on this to the Ministry; while of the other matters I will just refer to you with the following. We must be determined and once the blow has been inflicted, we must maintain it at all costs».

$\left({ }^{18}\right)$ Timoteo Bertelli in his Appunti storici storici intorno alle ricerche sui piccoli e spontanei moti dei pendoli fatte dal secolo XVII in poi, in Bullettino di Bibliografia e di Storia delle Scienze matematiche e Fisiche, 1873, on p. 28 he reports a letter of Antoine d'Abbadie in which the French astronomer and explorer recalls that he had frequently observed in a small tank full of mercury installed in his observatory at Abbadie, the oscillations produced by the microscopic earthquakes.

$\left({ }^{19}\right)$ The study of an earthquake from the point of view of its recordings and the consequent determination of its parameters requires that all the recordings be synchronised in regard to the same universal time.

\section{REFERENCES}

BATLLó, J. (2009): Influence of G. Grablovitz in Spain: instruments and scientific correspondence, this issue.

CALoI, P. (1958): About Some Phenomena Preceding and Following the Seismic Movements in the Zone Characterized by High Seismicity, in H. Benioff, M. Ewing, B. J. Howell Jr and F. Press eds., Contributions in Geophysics in Honor of Beno Gutenberg, London.

Cerini, M. and G. FerRARI (2009): The Seismological correspondence at the Observatory of the Alberoni College in Piacenza, this issue.

EUROSEISMOS website 2002-2009, http://storing.ingv.it/es_web.

FERRARI, G. (Ed.) (1991): Tromometri, avvisatori, sismografi. Osservazioni e teorie dal 1850 al 1880, (INGSGA, Bologna).

FERRARI, G. (1992a): The Origin and Development of a
Method of Measurement in Early Seismology, in Proceedings of the XI Scientific Instruments Symposium, (Bologna 9-14 September 1991), 179-189.

FERRARI, G. (1992b): Two hundred years of seismic instruments in Italy 1731-1940, (ING-SGA, Bologna).

FERrari, G. (Ed) (1997a): Proceedings of the Workshop Historical seismic instruments and documents a heritage of great scientific and cultural value, (Walferdange (Luxembourg) 16-18 May 1994, Luxembourg).

FERRARI, G. (1997b): Seismology in Europe: cultural heritage and scientific value, in Proceedings of the Workshop Historical seismic instruments and documents a heritage of great scientific and cultural value, edited by G. Ferrari, (Walferdange (Luxembourg) 16-18 May 1994, Luxembourg).

FerraRI, G. (1998): Seismic instruments, in Science of the Earth. An encyclopaedia of events, people and phe- 
nomena, edited by G. GooD, Garland, 462-470.

FERRARI, G. (2000): The new IASPEI Sub-Committee Historical instruments and related documents in seismology: goals, objectives and first results, in «Proceedings of the XXII IUGG General Assembly, Birmingham, 19-30 July 1999», Seismological Research Letters, 71 (5), 553-561.

FERRARI, G. (Ed.) (2004-2007): Viaggio nelle aree del terremoto del 16 dicembre 1857, 4 voll., 2 DVD-ROM, pp. $500+503+412+510$.

FERRARI, G. (2007a): La documentazione del Ministero della Polizia Generale sul passaggio di Mallet, Bernoud e Grillet nel Regno di Napoli nei paesi colpiti dal terremoto del 16 dicembre 1857, in Ferrari 2004-2007, 4, 9-94.

FERRARI, G. (2009): Giulio Grablovitz (1846-1928) and his scientific activity based on personal and institutional correspondence, this issue.

FERRARI, G. and M.G. BIANCHI (1997): Census filing and elaboration of scientific correspondences in seismology, in Proceedings of the Workshop Historical seismic instruments and documents a heritage of great scientific and cultural value, edited by G. FERRARI, (Walferdange (Luxembourg) 16-18 May 1994, Luxembourg), 185-194.

FERRARI, G. and A. MCCONNELL (2005): Robert Mallet and the 'Great Neapolitan Earthquake' of 1857, Notes and Records of the Royal Society of London, 59 (1), 45-64.

Ferrari, G., D. Albarello and G. Martinelli (2000): Tromometric measurements as a tool for crustal deformation interpretation, in «Proceedings of the XXII IUGG General Assembly, Symposium ST7, Birmingham, 19-30 July 1999», Seismological Research Letters, 71 (5), 562-569.

Grablovitz, G. (1911): Il mareografo d'Ischia in relazione ai bradisismi, Bollettino della Società Sismologica Italiana, 15, 144-153.

Guidoboni, E. and G. FerRARI (1987): Mallet's macroseismic survey on the Neapolitan Earthquake of 16th December, 1857, 4 voll., (Bologna, Italy).

GutenBERG, B. (1944): Energy Ration of reflected and refracted seismic waves, Bulletin of the Seismological Society of America, 34, 85-102.

HJORTENBERG, E. (2009): Inge Lehmann's work materials and seismological epistolary archive, this issue.

LEHMANN, I. (1971): William Bowie Medal to Inge Lehmann, Acceptance and response by Inge Lehmann, EOS, 52, 538.

MALLET, R. (1862): Great Neapolitan earthquake of 1857. The first principle of observational seismology, 2 voll., London (Reprinted in GUIDOBONI and FERRARI, 1987).

OMORI, F. (1911): On the recent sea-level variation at the Italian and Austrian mareograf stations, and on the cause of the Messina-Reggio earthquake of 1908, Bulletin of the Imperial Earthquake Investigation Committee, $\mathbf{5}$ (2), 87-100.

TARABUSI, G. and G. FerRARI (2009): Information Technology tools for the valorisation of Seismology's Historical Documentary Heritage, this issue.

TROMOS website 1997-2009, http://storing.ingv.it/tromos. 